\title{
Antinociceptive and Anti-inflammatory Effects of Hydroalcoholic Extract of Leaves of Piptadenia gonoacantha (Mart.) Macbr. in Experi- mental Animal Models
}

\author{
Efeitos antinociceptivo e anti-inflamatório do extrato das folhas de Piptadenia \\ gonoacantha (Mart.) Macbr. em modelos experimentais animais \\ Camilo A. de Carvalho ${ }^{* 1}$, Gabriela S. Santana ${ }^{2}$, Marilane de O.F. Amaro ${ }^{1}$, \\ Adriane J. Franco ${ }^{2}$, Rogério Pinto ${ }^{2}$, Ricardo A. Zatti ${ }^{2}$, Cláudio C. Fonseca ${ }^{3}$, \\ Silvia A. Cardoso ${ }^{1}$, Marcelo Barcellos da Rosa ${ }^{4}$, Leandro L. de Oliveira ${ }^{3}$ \\ ${ }^{1}$ Department of Medical and Nursing,UFV, Viçosa, MG, Brazil. \\ ${ }^{2}$ Department of Pharmacy, School of Biological and Health Sciences - UNIVIÇOSA, Viçosa, MG, Brazil. \\ ${ }^{3}$ Departament of General Biology, UFV, Av PH Rolfs, Viçosa, MG, Brazil. \\ ${ }^{4}$ Department of Chemistry, UFSM, Santa Maria, RS, Brazil.
}

\begin{abstract}
This study aimed to evaluate the anti-inflammatory and antinociceptive effects of hydroalcoholic extract of P.gonoacantha leaves (EPG). The toxic effect of the EPG was tested against A.salina in order to determine a secure dose for subsequent assays. The antinociception was evaluated using the acetic acid-induced writhing and hot plate tests in Wistar rats. The anti-inflammatory effect of EPG was evaluated by carrageenan-induced paw edema tests in rats. The bioassay with A.salina showed low toxicity of $E P G\left(L C_{50}=1,508 \mathrm{mg} / \mathrm{L}\right)$. Oral administration of EPG (50, 100 and $150 \mathrm{mg} / \mathrm{kg})$ significantly decreased the number of acetic acid-induced writhes, around $61.3 \%$, $71.8 \%$ and $64.9 \%$ respectively. However, EPG failed to prolong the latency time in the hot plate test, suggesting that EPG predominantly inhibits peripheral pain mechanisms. The oral administration of EPG at doses of 50 and $100 \mathrm{mg} / \mathrm{kg}$ significantly inhibited paw edema at $3 \mathrm{rd}$ h after the injection of the phlogistic agent by $34.5 \%$ and $37.5 \%$, respectively. These data suggest that EPG has both antinociceptive and anti-inflammatory activities, and these effects may be attributed to inhibition of COX-2 and prostaglandin release.
\end{abstract}

Keywords: Analgesic, Herbal Medicines, Inflammation.

\section{Resumo}

Este estudo teve como objetivo avaliar os efeitos anti-inflamatórios e antinociceptivos do extrato das folhas de $P$. gonoacantha (EPG). O efeito tóxico de EPG foi testado contra A. salina, a fim de determinar a dosagem segura para os ensaios subsequentes. A antinocicepção em ratos Wistar foi avaliada utilizando o modelo de contorções abdominais induzidas por ácido acético e testes em placa aquecida. O efeito anti-inflamatório de EPG foi avaliada por testes de edema da pata induzido por carragenina em ratos. O bioensaio com A. salina mostrou uma baixa toxicidade do EPG $\left(L C_{50}=1,508 \mathrm{mg} \cdot \mathrm{L}^{-1}\right)$. A administração oral de $E P G\left(50,100\right.$ e $\left.150 \mathrm{mg} \cdot \mathrm{kg}^{-1}\right)$ reduziu significativamente o número de contorções induzidas por ácido acético, em torno de 61,3\%, 71,8\% e 64,9\%, respectivamente. No entanto, o EPG não prolongou o tempo de latência no teste da placa quente, o que sugere que EPG iniba predominantemente os mecanismos de dor periférica. A administração oral de EPG, em doses de 50 e $100 \mathrm{mg} . \mathrm{kg}^{-1}$ inibiu significativamente o edema de pata após $3 \mathrm{~h}$ de administração do agente flogístico em 34,5\% e 37,5\%, respectivamente. Estes dados sugerem que a EPG possui atividade tanto antinociceptiva como antiinflamatória, podendo estes efeitos ser atribuídos à inibição da COX-2 e libertação de prostaglandinas.

Palavras-chave: Analgésico, plantas medicinais, inflamação

*camilo.carvalho@ufv.br

Recebido: 08/04/2014 Aceito: 08/04/2014 


\section{Introduction}

$\mathrm{T}$ he inflammatory reaction, typically characterized by redness, swelling, heat, and pain, is one of the most common manifestations of many diseases afflicting millions of people worldwide (Rang et al., 2011). The inflammation is the main of host defense mechanisms against invading pathogens. However, persistent or over inflammation leads to tissue damage and possibly failure of organs.

Numerous studies have been carried out to develop more powerful anti-inflammatory drugs with lesser side effects, and the interest researches on herbal medicines for producing drugs that are more efficient has been intensified in recent years (Rates, 2001; Castardo et al., 2008). Approximately $48 \%$ of drugs used in therapy come directly or indirectly from natural products, especially medicinal plants (Balunas and Kinghorn, 2005).

Piptadenia gonoacantha (Leguminosae - Mimosoideae) is a common tree species native to Atlantic Forest in southern and southeastern Brazil. This species is easily identified by its bark with longitudinal wings filled with woody spines present on the trunk and branches. The plant is commonly used in folk medicine to treat inflammatory disorders, and popularly known as "pau jacaré" (alligator stick). Phytochemical studies have be performed on the composition of P. gonoacantha, and a number of compounds have been identified such as triterpenes (friedelin, lupenone, lupeol, cycloartenone, cycloartan-25-26-en-3-one, 24-methylene-cycloartanone, and 24-methylenecycloartanol), steroids (sitosterol, campesterol, and stigmasterol), saponin (sitosterol-3-O - $\beta$-D-glucopyranoside), flavonoids (apigenin, 5-methylapigenin, 7,4'-dihydroxy-3',5-dimethoxyflavone, vitexin, and isovitexin), asperphenamate and methyl gallate (Carvalho et al., 2010). However, no research has been investigated on the analgesic and anti-inflammatory activity of $\mathrm{P}$. gonoacantha yet.

In this study, we investigated the analgesic and anti -inflammatory activities of the hydroalcoholic extract of P. gonoacantha (EPG) following oral administration in experimental animal models. The analgesic activity was evaluated by acetic acid-induced writhing response and hot plate test. Anti-inflammatory activity was determined by using carrageenan-induced paw edema model.

\section{Materials and methods}

\subsection{Plant material and extract preparation}

Fresh leaves of Piptadenia gonoacantha were collected in Viçosa, MG, Brazil. The plant material was identified and the voucher specimen $\left(\mathrm{n}^{\circ} .35530\right)$ is deposited in the herbarium of Federal University of Viçosa.

The leaves of $\mathrm{P}$. gonoacantha were air dried at $40^{\circ} \mathrm{C}$ and the dried material was then powdered using a knife mill (Marconi, Brazil). The hydroalcoholic extract was prepared according to Carvalho et al. (2011). Briefly, 200g of dried powder was submitted to ultrasound-assisted extraction in aqueous ethanol $(80 \%)$ for $1 \mathrm{~h}$ at $40{ }^{\circ} \mathrm{C}$. The extract was filtrated and evaporated to dryness using a rotavapor Q344B1 (Quimis, Brazil). The solutions of hydroalcoholic extracts of P. gonoacantha leaves (EPG) was prepared by dissolving a given quantity of the ethanolic extract in a small volume of dimethylsulfoxide (DMSO) and made up to the appropriate volume with physiological saline.

\subsection{Phytochemical group tests}

The ethanolic extracts of $P$ gonoacantha were screened by using standard procedures of phytochemical group tests (Simões et al., 2004). The extracts were screened for the presence of alkaloids, anthraquinones, cardiotonic heterosides, coumarins, flavonoids, phenolic compounds, saponins, tannins, and terpenoids. The reagents were first tested by using standard drugs of corresponding groups available in market.

\subsection{Brine shrimp lethality assay}

In vitro preliminary cytotoxicity assay was performed according to the method of Meyer et al. (1982) adapted by Carvalho et al. (2009). Briefly, brine shrimp (Artemia salina) nauplii were hatched in sterile brine solution (prepared using sea salt $38 \mathrm{~g} / \mathrm{L}$ and adjusted the $\mathrm{pH}$ to 8.5 using $1 \mathrm{~N} \mathrm{NaOH}$ ) under constant aeration at $25^{\circ} \mathrm{C}$ for 48 hours. After hatching, 10 nauplii were placed in each vial and various concentrations of EPG (250, 500, $1000,1500,2000$ and $2500 \mathrm{mg} / \mathrm{L}$ ) were added to each vial in a final volume of $5 \mathrm{~mL}$ and maintained at $37^{\circ} \mathrm{C}$ for 24 hours. The mortality end point of the bioassay was determined as the absence of controlled forward motion during 30 seconds of observation. Negative and positive controls were simultaneously performed using the same concentrations of the working solvent and $\mathrm{K}_{2} \mathrm{Cr}_{2} \mathrm{O}_{7}$ $(0.33 \mathrm{mM})$, respectively. The assays were performed in triplicate and calculate $\mathrm{LC}_{50}$ (the concentration of extract which caused 50 per cent mortality) based on Litchifield \& Wilcoxon method (Litchfield and Wilcoxon, 1949).

\subsection{Animals}

Female albino Wistar rats (190-210 g) were obtained from the central animal house of the Federal University of Viçosa - UFV. They were kept at standard environmental conditions (12/12-h light/dark cycle) at the animal house of the School of Biological and Health Sciences - UNIVIÇOSA and were allowed free access to food and water. Before each test, the animals were fasted for $12 \mathrm{~h}$ with free access to water. The rats were randomly divided into tests and controls groups $(n=6)$ as will be 
described further below.

The experimental protocol used in this study was approved (0006/2011-I) by the Ethics Committee of the School of Biological and Health Sciences - UNIVIÇOSA, and conforms with the Brazilian College for Animal Experimentation (COBEA) and with actual Brazilian legislation.

\subsection{Writhing test}

The antinociceptive activity of EPG was performed according to the method of Dutra et al. (2006). Acetic acid solution $0.6 \%(0.25 \mathrm{~mL} / \mathrm{animal})$ was injected intraperitoneally, and the constriction of the abdominal muscles together with stretching of the hind limbs was counted over a $20 \mathrm{~min}$ period starting $5 \mathrm{~min}$ after acetic acid injection. EPG (50, 100, and $150 \mathrm{mg} / \mathrm{kg}$, P.O.), indomethacin $(10 \mathrm{mg} / \mathrm{kg}$, P.O.) as the standard drug (positive control), and vehicle $(1 \mathrm{~mL}$ of $1 \%$ DMSO in saline, P.O.) as the negative control were administered 30 minutes before the acetic acid injection. The results were expressed as the mean number of writhing accumulated over $20 \mathrm{~min}$ experimental evaluation.

\subsection{Hot Plate Test}

The hot plate test was used to measure response latencies according to the method previously described by Eddy and Leimbach (1953). The hot plate was maintained at $54 \pm 1^{\circ} \mathrm{C}$. The time taken (in seconds) to cause a discomfort reaction (licking paws or jumping) was recorded as the response latency $30 \mathrm{~min}$ after administration of EPG (50, 100, and $150 \mathrm{mg} / \mathrm{kg}$, P.O.), indomethacin (10 $\mathrm{mg} / \mathrm{kg}$, P.O.) as positive control, and vehicle ( $1 \mathrm{~mL}$ of $1 \%$ DMSO in saline, P.O.) as the negative control. A latency period of $10 \mathrm{sec}$ was defined as complete analgesia. To avoid tissue injury, the experiment was stopped if the latency period was exceeded.

\subsection{Paw edema tests}

The anti-inflammatory effects of EPG were evaluated using the carrageenan-induced paw edema test in rats, according to the method of Ceccherelli et al. (1996). Briefly, rats were injected subplantarly into the right hind paw with $50 \mu \mathrm{L}$ of carrageenan suspension (1\% in saline). The left hind paw was injected with $50 \mu \mathrm{L}$ of saline and used as a control. The paw diameters of each group were measured prior to and 1,2, and 3 hours after carrageenan administration using a digital caliper (Marbeg). EPG (250, 500, and $750 \mathrm{mg} / \mathrm{kg}$, P.O.) was administered 30 minutes prior to carrageenan injection. The control group received an equivalent volume of water. Indomethacin $(10 \mathrm{mg} / \mathrm{kg}$, P.O. $)$ was used as the reference drug. The percent inhibition of edema was calculated.
All data are expressed as Mean \pm SEM. The result was tested by One-Way ANOVA and Dunnett post test (GraphPad Prism 5.0, USA). P $<0.05$ was considered statistically significant.

\section{Results}

The hydroalcoholic extracts of P. gonoacantha (EPG) submitted to phytochemical screening revealed the presence of flavonoids, phenolic compounds, and tannins. The resulting data are summarized in Table 1.

In vitro cytotoxic activity of EPG using brine shrimp lethality assay revealed that these compounds inhibited the Artemia salina nauplii in a dose dependent manner (fig. 1). The $\mathrm{LC}_{50}$ values of EPG was found to be 1,508 $\mathrm{mg} / \mathrm{L}$, that indicates a low toxicity of the extract.

Oral administration of $0.6 \%$ acetic acid produced a substantial number of writhes in control rats pretreated with vehicle ( $1 \mathrm{~mL}$ of $1 \%$ DMSO in saline) (Fig. 2). EPG $(50,100$, and $150 \mathrm{mg} / \mathrm{kg})$ significantly decreased the number of acetic acid-induced writhes (Fig. 2). $100 \mathrm{mg} / \mathrm{kg}$ of EPG showed best results reducing the writhes by $71.8 \%$. $50 \mathrm{mg} / \mathrm{kg}$ and $150 \mathrm{mg} / \mathrm{kg}$ of EPG produced $61.3 \%$ and $64.9 \%$ reduction in writhes, respectively. These results were found to be highly significant compared with the control group. However, oral administration of EPG (50, 100, and $150 \mathrm{mg} / \mathrm{kg}$ ) failed to prolong significantly the latency time compared with control animals in the hot plate test (Fig. 3). Indomethacin $(10 \mathrm{mg} / \mathrm{kg})$ the positive control used in this study produced inhibition of writhing movements, about $43.1 \%$ and prolongs the latency time significantly (Fig. 3).

TABLE 1. Phytochemical analysis of EPG.

\begin{tabular}{|c|c|c|}
\hline Phytochemical & Test & EPG \\
\hline \multirow{3}{*}{ Alkaloids } & Dragendorff & - \\
\hline & Hager & - \\
\hline & Mayer & - \\
\hline Anthraquinones & Borntrager & - \\
\hline Cardiotonic & Baljet & - \\
\hline heterosides & Kedde & - \\
\hline Coumarins & Potassium hydroxide & - \\
\hline \multirow{3}{*}{ Flavonoids } & Shinoda & + \\
\hline & Ferric chloride & + \\
\hline & Aluminum chloride & + \\
\hline $\begin{array}{l}\text { Phenolic } \\
\text { compounds }\end{array}$ & Folin-Ciocalteu & + \\
\hline Saponins & Honeycomb froth & - \\
\hline \multirow{2}{*}{ Tannins } & Iron salts & + \\
\hline & Gelatin-salt & + \\
\hline Terpenoids & Liebermann-Burchard & - \\
\hline
\end{tabular}

-: Absent; +: present 


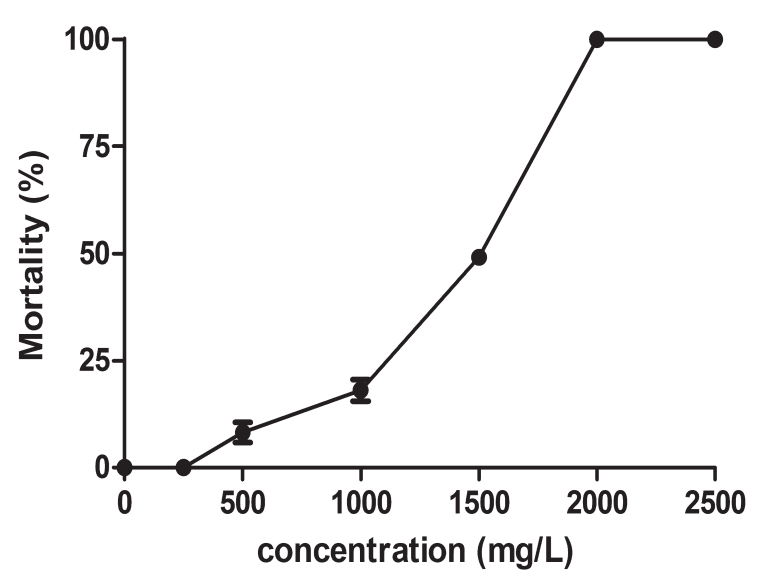

FIGURE 1. Artemia salina (brine shrimp) lethality test of EPG. Dilutions of a hydroalcoholic extracts of $P$. gonoacantha, were incubated with A. salina and the percentage mortality was monitored after $24 \mathrm{~h}$ exposure on different concentrations of the extracts.

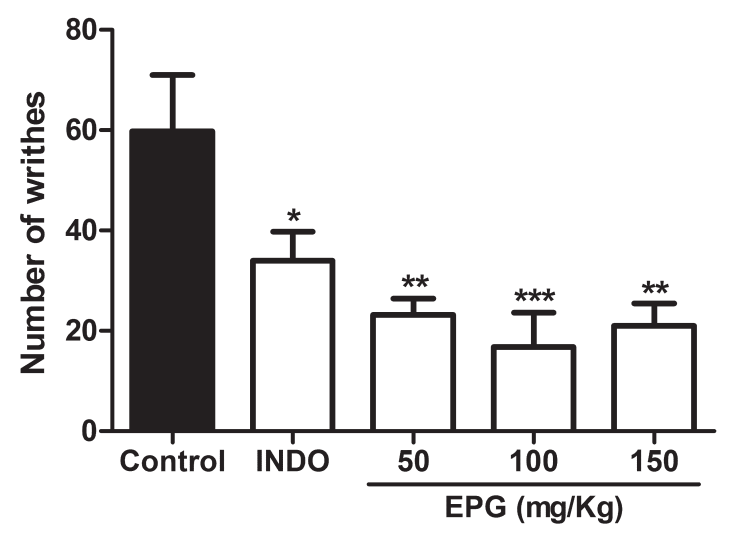

FIGURE 2. Antinociceptive effects of oral administration of EPG (50,100, and $150 \mathrm{mg} / \mathrm{kg}$ ) and indomethacin $(10 \mathrm{mg} / \mathrm{kg})$ on acetic acid-induced writhing response in rats. Each value represents mean $\pm \operatorname{SEM}(n=6)$. The number of abdominal writhes was counted over the time period of $5-25 \mathrm{~min}$ after acetic acid injection. ${ }^{*} \mathrm{P}<0.05,{ }^{* *} \mathrm{P}<0.01$ and ${ }^{* * *} \mathrm{P}<0.001$ as compared to the control group (one-way ANOVA followed by Dunnett's test).

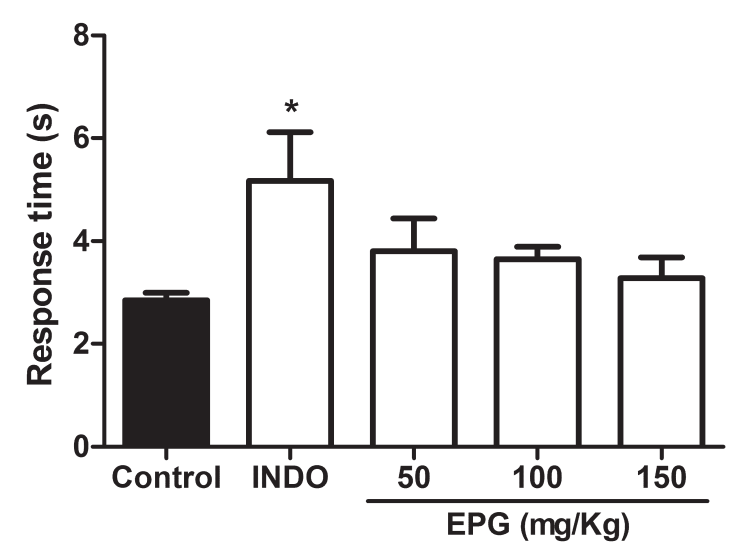

FIGURE 3. Effect of oral administration of EPG (50, 100 , and $150 \mathrm{mg} / \mathrm{kg}$ ) and indomethacin $(10 \mathrm{mg} / \mathrm{kg})$ on the pain threshold of mice in the hot plate test. Data are mean \pm SEM values for response time. ${ }^{*} \mathrm{P}<0.05$ compared to the control group (one-way ANOVA followed by Dunnett's test).

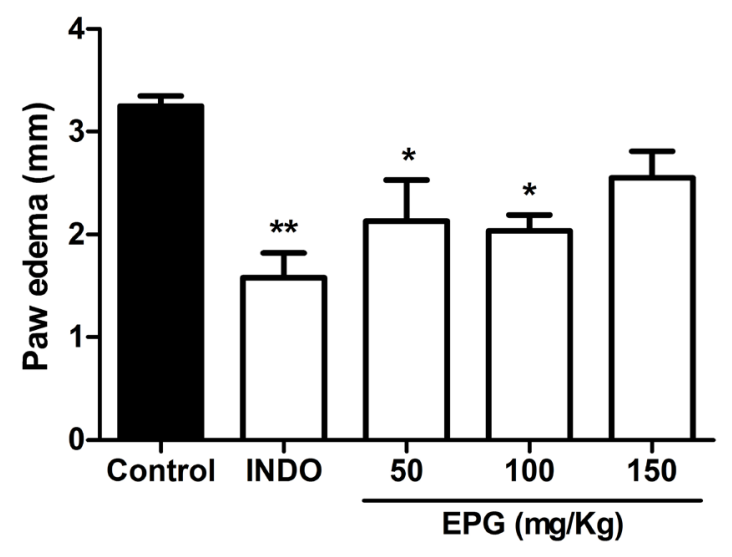

FIGURE 4. Effect of oral administration of EPG (50, 100 and $150 \mathrm{mg} / \mathrm{kg})$ and indomethacin $(10 \mathrm{mg} / \mathrm{kg})$ on carrageenan-induced rat paw edema. The paw edema volume was taken at the 3rd hour after carragegenan injection. Each column represents the mean \pm SEM. $(\mathrm{n}=6) .{ }^{*} \mathrm{P}<0.05$ and ${ }^{* *} \mathrm{P}<0.01$ as compared to the control group (one-way ANOVA followed by Dunnett's test).

TABLE 2. Effect of the administration of hydroalcoholic extracts of P. gonoacantha (EPG) on carrageenaninduced edema rat paw.

\begin{tabular}{|c|c|c|c|c|c|c|c|}
\hline \multirow[t]{2}{*}{ Groups } & \multirow{2}{*}{$\begin{array}{l}\text { Dose } \\
(\mathrm{mg} / \mathrm{kg})\end{array}$} & \multicolumn{3}{|c|}{ Paw volume increase } & \multicolumn{3}{|c|}{ Inhibition (\%) } \\
\hline & & $1 \mathrm{~h}$ & $2 \mathrm{~h}$ & $3 \mathrm{~h}$ & $1 \mathrm{~h}$ & $2 \mathrm{~h}$ & $3 \mathrm{~h}$ \\
\hline Control & & $1.54 \pm 0.37$ & $2.35 \pm 0.17$ & $3.25 \pm 0.10$ & & & \\
\hline INDO & 10 & $0.75 \pm 0.17$ & $1.38 \pm 0.27$ & $1.58 \pm 0.24^{* *}$ & 51.3 & 41.3 & 51.4 \\
\hline EPG & 50 & $0.86 \pm 0.13$ & $1.59 \pm 0.36$ & $2.13 \pm 0.40^{*}$ & 44.1 & 32.3 & 34.5 \\
\hline EPG & 100 & $0.68 \pm 0.02^{*}$ & $1.42 \pm 0.12$ & $2.03 \pm 0.15^{*}$ & 55.8 & 39.6 & 37.5 \\
\hline EPG & 150 & $1.24 \pm 0.14$ & $2.32 \pm 0.12$ & $2.55 \pm 0.26$ & 19.5 & 1.3 & 21.5 \\
\hline
\end{tabular}

The results are expressed as Mean $\pm \mathrm{SEM}(\mathrm{n}=6)$. INDO - indomethacin. ${ }^{*} \mathrm{P}<0.05,{ }^{* *} \mathrm{P}<0.01$, ANOVA followed by Dunnett's test. 
Carrageenan (1\%) injected into the subplantar of the right hind paws of the rats pretreated with vehicle $(1 \%$ DMSO in saline) caused an acute inflammatory response. The edema reached its maximum intensity $3 \mathrm{~h}$ after injection after administration of the phlogistic agent. The oral administration of EPG at doses of 50, and $100 \mathrm{mg} /$ $\mathrm{kg}$ significantly inhibited paw edema at $3 \mathrm{rd} \mathrm{h}$ after the injection (Fig. 4 and Table 2). EPG at the concentrations of 50 and $100 \mathrm{mg} / \mathrm{kg}$ had about equal amount of inhibition as $34.5 \%$ and $37.5 \%$, respectively. Indomethacin (10 $\mathrm{mg} / \mathrm{kg}$ ) profoundly reduced the carrageenan-induced edema in the right hind paws of rats, around $51.4 \%$ at 3rd h of measurement (Fig. 4).

\section{Discussion}

The World Health Organization (WHO) considers a toxic substance that has $\mathrm{LC}_{50}>1000 \mathrm{mg} / \mathrm{L}$ for brine shrimp lethality assay (WHO, 1965; Meyer et al., 1982). Anyway the EPG LC $_{50}$ was 10 times greater than the greatest dose used in antinociceptive and anti-inflammatory assays, the EPG did not induce lethality or any other signs of toxicity at doses up to $250 \mathrm{mg} / \mathrm{L}$. The high LC50 values also suggest that EPG were relatively safe and nontoxic to the animals.

Two different antinociceptive testing methods were employed in the current investigation, with the objective of identifying possible peripheral (acetic acid-induced writhing test) and central (hot plate test) effects. EPG exhibited significant antinociceptive activity against chemical stimuli (acetic acid tests), but not against thermal stimuli, suggesting that EPG predominantly inhibits peripheral, rather than central, pain mechanisms. Acetic acid indirectly triggers the release of nociceptive endogenous mediators (such as bradykinin, serotonin, and prostaglandin) to cause painful sensation (Liao et al., 2012). Since EPG also attenuated acetic acid-induced writhing, it is probable that the plant species may be producing its antinociceptive activity by affecting the prostaglandin system.

Carrageenan-induced edema is an experimental animal model for acute inflammation and it is a biphasic response. In the early phase (1-2h) of this assay is mainly mediated by histamine, serotonin and an increasing synthesis of prostaglandins in the damaged tissue surroundings. The late phase is sustained by prostaglandin release (Antonio and Souza Brito, 1998). Our data showed that EPG demonstrated antinociceptive activity against chemical stimuli and inhibited the formation of the carragegenan-induced rat paw edema, these effects might be partially related to inhibition of prostaglandin synthesis (Fig. 5). Prostaglandins (PGs) are responsible for inflammation features, and cyclooxygenase (COX) enzymes catalyze the first steps in their biosynthesis (Teather et al., 2002). COX-2 is referred to as the inducible isoform of COX, since levels of COX-2 increase in response to several stimulus, including inflammation process (Berenguer et al., 2002; Teather et al., 2002).

Substances present in the plant extracts may interfering with the initiation of the inflammatory response (Castardo et al., 2008).

In EPG was identified presence of flavonoids like apigenins, vitexin, and isovitexin (Carvalho et al., 2010), which have previously demonstrated to possess antinociceptive and anti-inflammatory activities (Mills and Bone, 2000; Jeong et al., 2009; Alves et al., 2012). Some flavonoids may interfere with inflammatory response by inhibiting COX-2 (Havsteen, 2002). Therefore, based on the results of this study, we can suggest that the antinociceptive and anti-inflammatory effect of EPG may be attributed to inhibition of COX-2 and prostaglandin release.

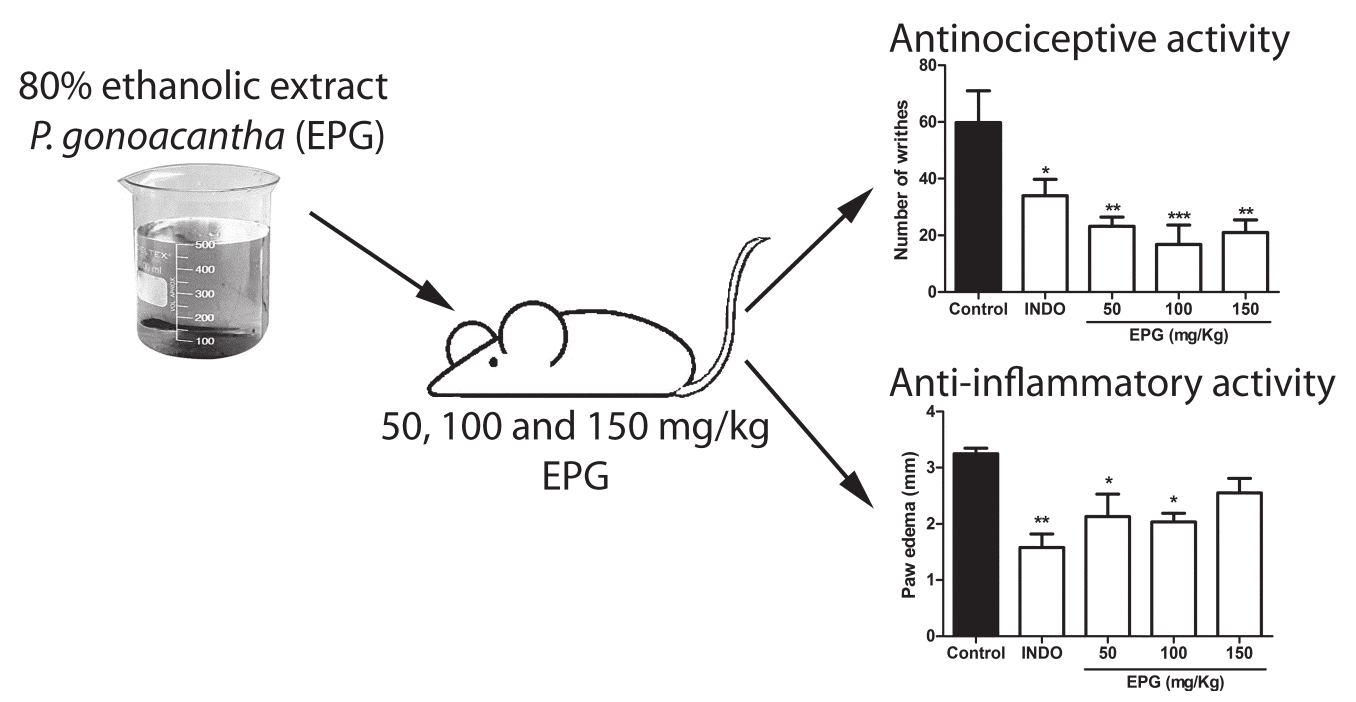

FIGURE 5. Graphical Abstract of antinociceptive and anti-inflammatory effects of hydroalcoholic extract of leaves of Piptadenia gonoacantha (Mart.) Macbr. in experimental animal models 


\section{Conclusion}

In conclusion, the data obtained show that $\mathrm{P}$. gonoacantha has both antinociceptive and anti-inflammatory activities, and that it has been used in folk medicine to treat inflammatory disorders, the obtained results corroborate the folkloric use this plant. In addition, this plant would be a good candidate for further development of a new phytotherapeutical medicine. Also, the obtained results in this work contribute significantly to the pharmacological validation for the safe use of P. gonoacantha. However, more studies are needed to further elucidate the mechanism of the antinociceptive and anti-inflammatory actions of $\mathrm{P}$. gonoacantha.

\section{Acknowledgement}

The authors are grateful to Mrs. Fernanda Lobão Gotti for authenticating the plant species. Also, we acknowledge the financial support supplied by CNPq, FAPEMIG and FUNARBE.

\section{References}

ALVES, C.Q.; DAVID, J.M.; DAVID, J.P.; VILLAREAL, C.F.; SOARES, M.B.P.; QUEIROZ, L.P.; AGUIAR, R.M. Flavonoids and other bioactive phenolics isolated from Cenostigma macrophyllum (Leguminosae). Quim. Nova v.35, p.1137-1140, 2012.

ANTONIO, M.A.; SOUZA BRITO, A.R. Oral antiinflammatory and anti-ulcerogenic activities of a hydroalcoholic extract and partitioned fractions of Turnera ulmifolia (Turneraceae). J. Ethnopharmacol. v.61, p.215-228, 1998.

BALUNAS, M.J.; KINGHORN, A.D. Drug discovery from medicinal plants. Life Sci. v.78, p.431-441, 2005.

BERENGUER, B.; ALARCON DE LA.; LASTRA, C.; MORENO, F.J.; MARTIN. M,J. Chronic gastric ulcer healing in rats subjected to selective and non-selective cyclooxygenase-2 inhibitors. Eur. J. Pharmacol. v.1-2, p.125-135, 2002.

CARVALHO, C.A.; FERNANDES, K.M.; MATTA, S.L.; SILVA, M.B.; OLIVEIRA, L.L.; FONSECA, C.C. Evaluation of antiulcerogenic activity of aqueous extract of Brassica oleracea var. capitata (cabbage) on Wistar rat gastric ulceration. Arq. Gastroenterol. v.48, p.276-282, 2011.
CARVALHO, C.A.; MATTA, S.L.P.; MELO,

F.C.S.A.; ANDRADE, D.C.F.; CARVALHO, L.M.; NASCIMENTO, P.C.; SILVA, M.B.; ROSA, M.B. Stem herb (Tynnanthus fasciculatus MIERSBignoniaceae): phytochemical and toxicological study involving Artemia. Rev. Eletr. Farm. v.6, p.51-58, 2009.

CARVALHO, M.G.; CARDOZO, M.A.; CATUNDA JUNIOR, F.E.; CARVALHO, A.G. Chemical constituents of Piptadenia gonoacantha J.F. Macbr. An. Acad. Bras. Cienc. v.82, p.561-567, 2010.

CASTARDO, J.C.; PRUDENTE, A.S.; FERREIRA, J.; GUIMARAES, C.L.; MONACHE, F.D.; FILHO, V.C.; OTUKI, M.F.; CABRINI, D.A. Antiinflammatory effects of hydroalcoholic extract and two biflavonoids from Garcinia gardneriana leaves in mouse paw oedema. J. ethnopharmacol. v.118, p.405-411, 2008.

CECCHERELLI, F.; GAGLIARDI, G.; MATTERAZZO, G.; VISENTIN, R.; GIRON, G. The role of manual acupuncture and morphine administration on the modulation of capsaicin-induced edema in rat paw. A blind controlled study. Acupuncture Electro. v.21, p.7-14, 1996.

DUTRA, R.C.; TAVARES, C.Z.; FERRAZ, S.O.; SOUSA, O.V.; PIMENTA, D.S. Investigation of analgesic and anti-inflammatory activities of Echinodorus grandiflorus rhizomes methanol extract. Braz. J. Pharmacog. v.16, p.469 - 474, 2006.

EDDY, N.B.; LEIMBACH, D. Synthetic analgesics. II. Dithienylbutenyl- and dithienylbutylamines. J. Pharm. Exp. Therap. v.107, p.385-393, 1953.

HAVSTEEN, B.H. The biochemistry and medical significance of the flavonoids. Pharmacol. Therapeut. v.96, p.67-202, 2002.

JEONG, G.S.; LEE, S.H.; JEONG, S.N.; KIM, Y.C.; KIM, E.C. Anti-inflammatory effects of apigenin on nicotine- and lipopolysaccharide-stimulated human periodontal ligament cells via heme oxygenase-1. Inter. Immunopharmacol. v.9, p.1374-1380, 2009.

LIAO, C.R.; KAO, C.P.; PENG, W.H.; CHANG, Y.S.; LAI, S.C.; HO, Y.L. Analgesic and AntiInflammatory Activities of Methanol Extract of Ficus pumila L. in Mice. Evid. Based Complement. Alternat. Med. Article ID 340141, 9 pages, 2012.

LITCHFIELD, J.T.; WILCOXON, F. A simplified method of evaluating dose-effect experiments. J. Pharm. Exp. Therap. v.96, p.99-113, 1949. 
MEYER, B.N.; FERRIGNI, N.R.; PUTNAM, J.E.;

JACOBSEN, L.B.; NICHOLS, D.E.; MCLAUGHLIN,

J.L. Brine shrimp: a convenient general bioassay for active plant constituents. Planta Med. v.45, p.31-34, 1982.

MILLS, S.; BONE, K. Principles and practice of phytotherapy. Churchill Livingstone, Edinburgh, 2000.

RANG, H.P.; DALE, M.M.; RITTER, J.M.; FLOWER, R.J.; HENDERSON, G. Anti-inflammatory and immunosuppressant drugs. Rang and Dale's Pharmacology. Elsevier Publications, Edinburgh, UK, p.226-245, 2011.

Rates, S.M. Plants as source of drugs. Toxicon v.39, p.603-613, 2001.

SIMÕES, C.M.O.; SCHNKEL, E.P.; GOSMANN, G.; MELLO, J.C.P.; MENTZ, L.A.; PETROVICK, P.R. Farmacognosia: da planta ao medicamento. Editora da UFRGS Florianópolis, 2004.

TEATHER, L.A.; MAGNUSSON, J.E.; WURTMAN, R.J. Platelet-activating factor antagonists decrease the inflammatory nociceptive response in rats. Psychopharmacol. v.163, p.430-433, 2002.

WHO. Molluscicide screening and evaluation.

Bulletin of the World Health Organization. v.33, p.567-581, 1965. 